\title{
Glucocorticoids and foetal heart maturation; implications for prematurity and foetal programming
}

\author{
Eva A Rog-Zielinska, Rachel V Richardson, Martin A Denvir and Karen E Chapman
}

Queen's Medical Research Institute, Centre for Cardiovascular Science, University of Edinburgh, Edinburgh EH16 4TJ, UK

Correspondence should be addressed to K E Chapman

Email

Karen.Chapman@ed.ac.uk

\begin{abstract}
Glucocorticoids are steroid hormones, essential in mammals to prepare for life after birth. Blood levels of glucocorticoids (cortisol in most mammals including humans; corticosterone in rats and mice) rise dramatically shortly before birth. This is mimicked clinically in the routine administration of synthetic glucocorticoids to pregnant women threatened by a preterm birth or to preterm infants to improve neonatal survival. Whilst effects on lung are well documented and essential for postnatal survival, those on heart are less well known. In this study, we review recent evidence for a crucial role of glucocorticoids in late gestational heart maturation. Either insufficient or excessive glucocorticoid exposure before birth may alter the normal glucocorticoid-regulated trajectory of heart maturation with potential life-long consequences.
\end{abstract}

\section{Key Words}

- glucocorticoids

- cardiovascular

- development

- embryo/foetus

adrenal hormones

Journal of Molecular Endocrinology (2014) 52, R125-R135

\section{Introduction}

Glucocorticoids are steroid hormones produced by the adrenal cortex. They regulate stress responses and exert potent immunomodulatory effects in adults (McEwen 1997) and are essential for the transition from foetal to neonatal life. Plasma levels of glucocorticoids rise markedly in late gestation, to mature foetal tissues and organs (Fowden et al. 1998) and this is mimicked clinically with the routine administration of synthetic glucocorticoids (betamethasone or dexamethasone) to pregnant women in whom preterm delivery is anticipated, to improve neonatal survival. Whilst there is no question that the enhancement of foetal lung maturity is life-saving, animal models and some studies on humans have raised concerns about long-term effects of synthetic glucocorticoid administration, particularly on the cardiovascular system. Although a number of studies have examined the mechanisms that underlie the effects of excess glucocorticoid exposure on the heart and vasculature, few have addressed the maturational pathways normally regulated by glucocorticoids in the foetal heart and vasculature. In this study, we present a non-systematic review of the evidence for a critical role of glucocorticoids in late gestational heart maturation and discuss the implications of both inadequate and excess glucocorticoid action within the late gestation foetal heart.

\section{Glucocorticoid receptors}

Glucocorticoids bind to cytoplasmic receptors belonging to the nuclear receptor superfamily; the widely distributed glucocorticoid receptor (GR, or the type II receptor) and the more restricted mineralocorticoid receptor (MR, the type I GR). Both exert effects predominantly through binding to DNA, though rapid non-genomic signalling has also been reported for both (reviewed Funder (1997), Buckingham (2006), Dooley et al. (2012) and

Published by Bioscientifica Ltd 
Samarasinghe et al. (2012)). GR is the major GR, whilst MR is only a GR in a restricted range of tissues or under certain pathological conditions (Funder 1997). Although MR has high intrinsic affinity for the endogenous glucocorticoids cortisol and corticosterone, it is normally specific for the mineralocorticoid, aldosterone, by virtue of the activity of an enzyme, 11ß-hydroxysteroid dehydrogenase type 2 (11 $\beta$-HSD2) which converts the physiological glucocorticoids cortisol and corticosterone to cortisone and 11-dehydrocorticosterone, respectively, preventing their inappropriate activation of MR (Chapman et al. 2013). MR expression is largely restricted to mineralocorticoid target tissues, but it is also expressed in the heart without $11 \beta$-HSD2 co-expression. Thus, in heart, MR binds endogenous cortisol/corticosterone avidly (Funder 2005). Of note, MR is poorly activated by betamethasone and dexamethasone, the potent synthetic glucocorticoids used in antenatal therapy.

GR has approximately tenfold lower affinity for physiological glucocorticoids than MR and does not bind aldosterone. In mice (Cole et al. 1995, Tronche et al. 1998) and most likely also humans (Charmandari et al. 2004), glucocorticoid action mediated via GR is essential for survival beyond birth. It is also important for survival in late gestation in mice; around $50 \%$ of $\mathrm{GR}^{-1-}$ foetuses die by E17.5 with characteristics of hydrops foetalis (Rog-Zielinska et al. 2013), a condition associated with intra-uterine death in humans that frequently results from heart failure (Bellini et al. 2009, Fritsch et al. 2012). In contrast, mice which lack MR survive birth, but die in the first 2 weeks of life of circulatory failure caused by renal salt-wasting (Berger et al. 1996, Bleich et al. 1999). Both GR and MR are expressed in the foetal heart (Brown et al. 2005) and while MR appears to play a detrimental role in adult cardiac remodelling (Messaoudi et al. 2012), how both receptors influence cardiac development and maturation remains poorly understood. GR is certainly present in the human heart from 12 weeks of gestation (Ballard \& Ballard 1974) and in mouse heart from as early as embryonic (E) day E10.5, though it is not activated by endogenous glucocorticoids until E15.5 (Rog-Zielinska et al. 2013). A critical role for GR signalling in foetal heart maturation has recently been demonstrated (Rog-Zielinska et al. 2013). However, the relationship between in utero glucocorticoid exposure and heart maturation appears to follow an inverted U-shaped pattern, typical of many glucocorticoid actions (Munck et al. 1984), with both low and excessive glucocorticoids having a detrimental impact on cardiovascular development. Whether these effects share a common mechanism remains unknown. Nonetheless, given the widespread use of antenatal glucocorticoids in preterm infants to promote lung maturation, it is important to understand the potential impact of this treatment on maturation and growth of the heart and vasculature.

\section{Glucocorticoid signalling in the foetus}

The timing and level of exposure to glucocorticoids in utero are the key determinants of their lifelong organisational effects upon tissues (Fowden et al. 1998, Seckl \& Holmes 2007). Inadequate glucocorticoid action can have potentially fatal consequences, yet premature activation of glucocorticoid-dependent pathways or excessive glucocorticoid levels during pregnancy can cause lifelong 'programmed' adverse cardiovascular effects (Benediktsson et al. 1993, Louey \& Thornburg 2005, Seckl \& Holmes 2007; and see below). Endogenous physiological foetal glucocorticoid production is tightly regulated, and increases markedly over a narrow time window shortly before birth (Fig. 1). The foetal adrenal gland initiates de novo glucocorticoid synthesis during the second half of gestation, at around the 28th week of pregnancy in humans (Mastorakos \& Ilias 2003) and

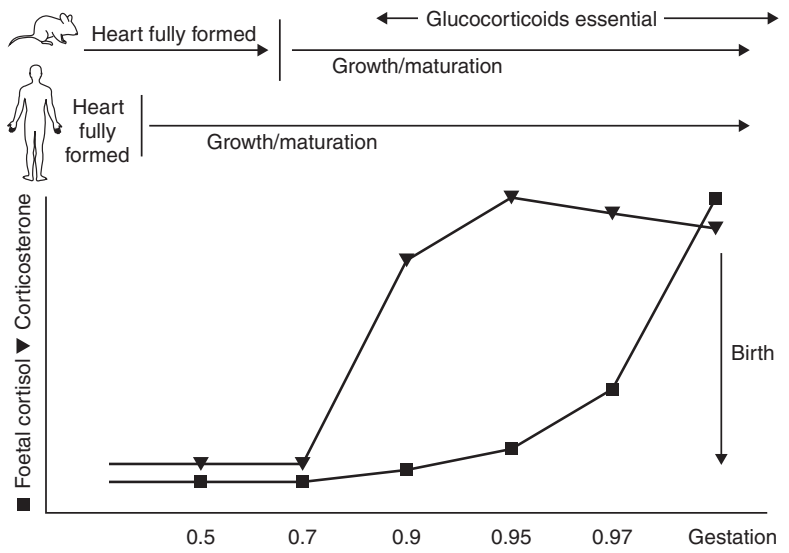

Figure 1

Glucocorticoids rise in the foetus in late gestation, coincident with the growth and maturation of the foetal heart. The foetal heart is fully formed in both mice ( $\sim$ E13.5-E14.5) and humans ( 40 days; indicated by vertical bars, top) before the glucocorticoid surge that occurs in the few days before birth in most mammals (Michelsohn \& Anderson 1992, Fowden et al. 1998, Henderson \& Anderson 2009). In mice, the late gestational increase in foetal plasma corticosterone (triangles in the schematic representation above) is essential for maturation of the foetal heart (Rog-Zielinska et al. 2013). In humans, the exact role of the rise in plasma cortisol levels (squares in the representation above) in maturation of the foetal heart remains poorly understood. However, both insufficient or excessive/mis-timed glucocorticoid exposure may have adverse effects on heart function over the long term (see text for details).

Published by Bioscientifica Ltd. 
E14.5 in mice (Michelsohn \& Anderson 1992). In mice, endogenous foetal plasma glucocorticoid levels increase rapidly from E15 (Michelsohn \& Anderson 1992) though in humans this physiological increase happens in the week before birth (Fowden et al. 1998). In addition, as pregnancy progresses into the final stage, maternal plasma glucocorticoid levels rise dramatically as a result of increased maternal glucocorticoid production and prolonged plasma half-life (Donaldson et al. 1991, Mastorakos $\&$ Ilias 2003), though placental 11ß-HSD2 restricts the access of maternal glucocorticoids to the foetus (Chapman et al. 2013). Placental 11ß-HSD2 activity declines in the last week of gestation in humans (Murphy \& Clifton 2003) and in mice (Brown et al. 1996, Thompson et al. 2002), allowing for transfer of maternal glucocorticoid to the foetus as birth approaches (Cottrell et al. 2012). These different effects combine to cause a surge in foetal glucocorticoid levels in late gestation, which act through GR to elicit the critical maturation of foetal lung (Cole et al. 1995, Nemati et al. 2008), skin (Bayo et al. 2008), liver (Opherk et al. 2004) and, importantly, heart (Rog-Zielinska et al. 2013). In addition to administration of exogenous glucocorticoids, foetal glucocorticoid exposure is potentially affected by a number of mechanisms including prematurity at birth, maternal stress, alterations in placental metabolism and adrenal disease.

\section{Late gestation cardiac maturation}

By late gestation, although the heart has attained its adult anatomical configuration, it continues to undergo extensive growth, remodelling and maturation to support the rapidly growing foetus and prepare for life after birth. Both systolic and diastolic function improve in late gestation (Harada et al. 1997, Corrigan et al. 2010), reflecting the improved contractility and relaxation properties of the cardiomyocytes. The ventricle walls progressively thicken (Webb et al. 1996, Christoffels et al. 2000), driven predominantly by cardiomyocyte hyperplasia (Oparil et al. 1984). As hyperplastic growth gives way to hypertrophic growth following birth, cardiomyocytes become binucleated, less spherical in shape and more rod-shaped allowing for more efficient mechanical and electrical coupling (Burrell et al. 2003, Hirschy et al. 2006). As these rod-shaped cardiomyocytes align with each other, the muscle fibres in the outermost layer of the compact myocardium form into spiraling bundles to create the typical architecture of the mature mammalian heart. The change in cardiomyocyte shape is underpinned by ultrastructural changes. Contractile proteins accumulate and switch from foetal to adult isoforms (myosin heavy chain and titin, for example) as myofibrils grow and align parallel to the long axis of the cardiomyocyte, acquiring more sarcomeres and well-defined Z-discs (Ehler et al. 1999, Siedner et al. 2003). Towards the end of gestation, the sarcoplasmic reticulum also swells and undergoes structural changes (Canale et al. 1986) in order to facilitate calcium-induced calcium release (Rapila et al. 2008). This is accompanied by marked changes in ion channel expression and activity, as electrical coupling in the heart matures in the time period close to birth (Davies et al. 1996). The late gestation heart also undergoes a significant metabolic transformation as it prepares to adjust to the high-oxygen extra-uterine environment and increased haemodynamic work load after birth. The number of mitochondria increase as cardiomyocytes switch from utilising carbohydrates (mainly glucose) as the predominant source of energy to fatty acids, a more efficient source of ATP (Bartelds et al. 2000). All of these morphological and functional changes enable the late gestation foetal heart to increase cardiac output as the foetus grows and prepare for the increase in cardiac work load at birth.

\section{Glucocorticoids, through GR, promote foetal heart maturation}

Mechanical and hormonal factors, including glucocorticoids, play important roles in cardiac maturation, although understanding the contribution made by endogenous glucocorticoids, particularly in rodents, can be difficult due to compensation between foetal and maternal hypothalamic-pituitary-adrenal (HPA) systems (Montano et al. 1993). Moreover, endogenous glucocorticoids, cortisol and corticosterone may act through either GR or MR. Recent work has shown that glucocorticoids act via GR to promote foetal heart maturation through both direct and indirect effects on cardiomyocytes (Rog-Zielinska et al. 2013). In the absence of glucocorticoid signalling, the late gestation foetal heart is immature and functions poorly. In $\mathrm{GR}^{-1-}$ mice or mice with tissuespecific disruption of GR in cardiomyocytes and vascular smooth muscle, the initial phase of contraction takes longer and the normal macro- and micro-architecture of the compact myocardium is disrupted (Rog-Zielinska et al. 2013). This is associated with immature cardiomyocyte ultrastructure featuring short and disorganised myofibrils (Rog-Zielinska et al. 2013). The normal maturational change in the expression of genes involved in calcium handling and energy metabolism that occurs between

Published by Bioscientifica Ltd. 
E14.5 and E17.5 (spanning the time of the glucocorticoid surge) is absent in $\mathrm{GR}^{-1-}$ mice (Rog-Zielinska et al. 2013). Not all of these gene-expression changes are a direct result of GR in cardiomyocytes and/or vascular smooth muscle cells (Rog-Zielinska et al. 2013), suggesting that extra-cardiac glucocorticoid actions mediated by GR are also key to late gestation heart maturation, possibly via haemodynamic changes. $\mathrm{GR}^{-1-}$ foetuses exhibit oedema, which must be due, at least in large part, to GR actions in cardiomyocytes and/or vascular smooth muscle, as specific knockout of GR in these cells also causes foetal oedema, albeit to a lesser extent. In contrast to prematurity, when birth occurs before the normal rise in endogenous cortisol levels (see below), the hydrops phenotype of late gestation $\mathrm{GR}^{-1-}$ foetuses is manifested following the onset of the glucocorticoid surge (Rog-Zielinska et al. 2013), raising the possibility that, in some cases, foetal glucocorticoid insufficiency or even glucocorticoid resistance may be a cause of non-immune hydrops foetalis in humans. Clinically, cardiogenic hydrops typically presents with impaired diastolic ventricular filling (Bellini et al. 2009), as seen in $\mathrm{GR}^{-1-}$ foetuses (though not in foetuses with cardiomyocytespecific GR knock-out). Glucocorticoids are an effective treatment in hydrops foetalis associated with congenital cystic adenomatoid malformations (CCAM; Tsao et al. 2003, Curran et al. 2010), although the therapeutic mechanism remains to be ascertained (Leung et al. 2005) and may relate to reduced mediastinal shift secondary to glucocorticoid-induced maturation or involution of the lung lesions, restoring cardiac venous return and improving contractility (Knox et al. 2006).

Whether MR plays a role in the glucocorticoidinduced maturation of cardiac structure and function is important and remains to be determined. However, cardiac MR mRNA levels are not affected by GR deficiency in utero (Rog-Zielinska et al. 2013).

\section{Insufficient glucocorticoid action: prematurity}

Preterm birth increases the risk of cardiovascular disease in later life (Crump et al. 2011). As preterm birth occurs before the physiological late gestation rise in foetal glucocorticoids and before foetal organs are mature enough for extra-uterine life, it is possible that perinatal glucocorticoid deficiency underlies this increased risk. Endogenous glucocorticoid action occurs under the control of the foetal HPA axis. Although the HPA axis can respond to a variety of stressors in prenatal and neonatal life, the magnitude and kinetics of the responses are dependent on developmental age (Walker et al. 1991). Thus, developmental immaturity in the preterm infant may be associated with a limited adrenal reserve. Relative adrenal insufficiency in preterm infants, with low serum cortisol or an inability to mount an adequate cortisol stress response, has been suggested as a contributory factor to haemodynamic instability and increased mortality in preterm infants (Ng et al. 2004, Nykänen et al. 2007, Fernandez \& Watterberg 2009).

Cardiovascular complications in premature infants include persistence of the ductus arteriosus (the foetal shunt that connects the pulmonary artery to the aorta, bypassing the lungs) and the foramen ovale (that allows blood to flow directly from the right to the left atrium, bypassing the right ventricle and the lungs), a delay in the normal decrease in pulmonary vascular resistance (the foetal lungs have a high resistance) and a delay in the necessary increase in cardiac output required to manage the additional volume load after birth (Huhta 2005). Consequently, haemodynamic instability is a wellrecognised problem in premature infants ( $\mathrm{Ng}$ et al. 2004, Kluckow 2005, Sehgal 2011) with hypotension and low systemic blood flow associated with increased mortality (Ibrahim et al. 2011). Many of these markers of prematurity are improved by exogenous glucocorticoid treatment. Glucocorticoids facilitate the closure of the ductus arteriosus by inhibition of prostaglandin $\mathrm{E}_{2}$ efficacy (Clyman et al. 1981, Eronen et al. 1993). They are also an effective treatment for refractory systemic hypotension in preterm infants, either alone or in combination with other volume expansion/ionotropic agents (Noori et al. 2006, Ibrahim et al. 2011). In foetal sheep, the normal late gestation increase in arterial blood pressure is abolished by adrenalectomy and restored by cortisol replacement (Unno et al. 1999), supporting a crucial role for endogenous cortisol secretion in achieving normal circulatory function.

Systolic function of the left ventricle, measured by cardiac output, fractional shortening, ejection fraction or left ventricular mass and diameter, is typically impaired in the preterm foetus compared with full-term neonates (Harada et al. 1999, Kozák-Bárány et al. 2001, Ciccone et al. 2011). In additiona, impaired diastolic function is increasingly recognised as an equally, if not more, important determinant of postnatal outcome. In a series of clinical studies, parameters of diastolic function such as the E-wave velocity and early-to-atrial filling ratios were significantly lower in preterm infants (Kozák-Bárány et al. 2001, Schmitz et al. 2004, Ciccone et al. 2011). Myocardial performance index, a measure of systolic and

Published by Bioscientifica Ltd. 
diastolic function that is independent of heart rate and size, is higher in preterm infants and strongly correlates with severity of pulmonary dysfunction and poor outcomes (Yates et al. 2008). Given the importance of GR signalling for the maturation of cardiac function in mice shortly before birth, it is plausible that insufficient or mistimed glucocorticoid signalling may contribute to these common cardiovascular complications. The short-term effects of glucocorticoids on heart function itself have been little investigated and are difficult to dissect from the more general haemodynamic effects. However, in immature baboons in which adrenal insufficiency was associated with impaired heart function (measured by fractional shortening and velocity of circumferential fibre shortening), a short course of neonatal cortisol led to a sustained improvement in cardiac performance (Yoder et al. 2002), consistent with a beneficial effect of glucocorticoid therapy on heart maturation.

Whether adrenal insufficiency and its associated haemodynamic instability results from prematurity per se, or as a consequence of antenatal glucocorticoid therapy, is an important question. A meta-analysis of 49 human studies assessed the impact of antenatal treatment with synthetic glucocorticoids and concluded that although basal HPA axis function recovered within 2 weeks of delivery, there was a sustained ( $>4-8$ weeks) suppression of the cortisol response to pain (Tegethoff et al. 2009), suggesting that antenatal glucocorticoid treatment itself may cause a persistent inability to mount a cortisol stress response. Thus, both immaturity and antenatal glucocorticoid therapy may result in a similar limited adrenal reserve in premature birth.

Although in humans it is difficult to separate the long-term effects of prematurity from the effects of glucocorticoid treatment and possible over- or mis-timed exposure, animal models are providing valuable information to support a 'programming' effect of early or excessive glucocorticoid exposure on the foetal cardiovascular system (Seckl \& Holmes 2007, Cottrell \& Seckl 2009).

\section{Precocious or excessive glucocorticoid action}

For two decades it has been recognised in animal studies that exposure to excessive glucocorticoid levels in utero, by bypassing or overwhelming placental $11 \beta$-HSD2, causes short-term effects such as foetal growth restriction and long-term effects that include increased risk of cardiovascular disease when the offspring reach adulthood (Benediktsson et al. 1993, Nyirenda et al. 1998). Maternal nutritional restriction, which prematurely activates the foetal HPA axis (Cottrell et al. 2012), also increases foetal glucocorticoid levels and 'programmes' greater risk of cardiovascular disease once adult (Langley-Evans et al. 1998, Roseboom et al. 2001), as does maternal stress, probably through increased maternal glucocorticoid levels (Seckl \& Holmes 2007, Bingham et al. 2013). Glucocorticoid and/or nutritional programming of adult disease has been extensively reviewed (for recent reviews see Seckl \& Holmes (2007), Langley-Evans (2013) and Reynolds (2013)). In addition, the reader is referred to a comprehensive recent review of the acute effects of betamethasone and dexamethasone on human foetal behaviour (movement/breathing) and haemodynamics (heart rate, Doppler velocity measurements of blood flow in the umbilical artery) (Mulder et al. 2009). In this study, we restrict our discussion to the impact of elevated glucocorticoid signalling on the maturation of the prenatal heart and its possible long-term consequences.

In vivo studies have largely focused on the ability of exogenous glucocorticoids to increase foetal heart size, which occurs despite a general restriction of foetal growth in humans and in animal models. However, whether this involves glucocorticoid-induced alterations in cardiomyocyte proliferation, binucleation and/or hypertrophy remains controversial. Moreover, foetal blood pressure, a well-known stimulus of myocardial maturation, is increased by exogenous glucocorticoids, further confounding interpretation. In some studies in rats and sheep, the glucocorticoid-induced increase in heart weight and protein:DNA ratio has been interpreted as late gestation cardiomyocyte hypertrophy, without proliferation (Slotkin et al. 1991, Rudolph et al. 1999, Jensen et al. 2002). Other studies report a higher proliferative index in hearts following antenatal glucocorticoid administration, suggesting hyperplasia rather than hypertrophy as the mechanism of glucocorticoid-induced heart enlargement (Torres et al. 1997, Giraud et al. 2006). Many studies do not report foetal haemodynamic effects of glucocorticoid administration. However, when cortisol was infused into the coronary artery of foetal sheep, hyperplasia was induced with only a modest increase in intracardiac cortisol (threefold) and without blood pressure changes (Torres et al. 1997, Giraud et al. 2006), suggesting a pro-proliferative effect of cortisol on cardiomyocytes. A recent study on mice has administered dexamethasone from E12.5 to E15 (before the normal glucocorticoid surge; O'Sullivan et al. 2013). Although this caused a transient decrease in foetal weight and a corresponding though non-significant decrease in foetal heart weight at E14.5, this had recovered by E17.5,

Published by Bioscientifica Ltd. 
possibly as a result of increased cardiac expression of insulin-like growth factor 1 , and cardiomyocyte number in adulthood was unchanged (O'Sullivan et al. 2013), suggesting compensatory myocardial growth once dexamethasone treatment stopped (though glucocorticoidregulated mRNAs remained elevated at E17.5, indicating a lasting effect of glucocorticoid action on foetal cardiomyocytes). However, the possibility of foetal HPA axis suppression by dexamethasone treatment was not examined in that study, so it is unclear whether the normal increase in glucocorticoid levels at E16.5-E18.5 occurred in the treated mice and it is likely that the late gestation trajectory of heart maturation was altered in response to dexamethasone. Differences in study outcomes are likely to result from different steroid regimes: dose, steroid used - cortisol (which binds to both GR and MR), betamethasone or dexamethasone (GR-selective) and/or timing. For example, experimental models using rats commonly use dexamethasone in late gestation, after the onset of the endogenous glucocorticoid surge, whereas sheep models have typically treated either much earlier (around 0.6 gestation) or in late gestation (shortly before the normal increase in foetal glucocorticoid levels) with dexamethasone, betamethasone or cortisol. Recent data implicate MR in cortisol-induced cardiomyocyte hyperplasia, with GR exerting anti-apoptotic effects in late gestation in sheep (Feng et al. 2013). Moreover, in mice with cardiomyocyte/vascular smooth muscle knockout of GR (and normal plasma glucocorticoid levels), heart size was similar to littermate controls at E17.5 (Rog-Zielinska et al. 2013), suggesting that the smaller hearts of $\mathrm{GR}^{-/-}$foetuses are an indirect result of glucocorticoid signalling and not a direct effect of GR in cardiomyocytes. Thus, increased heart size may result from stimulation of myocyte proliferation mediated by cortisol signalling through $\mathrm{MR}$, or may reflect indirect effects, most likely haemodynamic, mediated by GR elsewhere. This has implications for antenatal therapy if the synthetic glucocorticoids used cause hypertrophy but do not cause the normal increase in myocyte proliferation that normally occurs near term. It will be of interest to test whether mice with cardiomyocyte-specific knock-out of MR (Fraccarollo et al. 2011) have smaller hearts in late-gestation.

The physiological rise in endogenous foetal glucocorticoids is important for the maturation of electrical coupling in the foetal heart, and abnormalities in sodium channel expression linked to dysregulated plasma cortisol levels have been suggested as a cause of sudden infant death syndrome in premature infants
(Fahmi et al. 2004). In immature foetal sheep, cortisol infusion (before the normal rise) precociously increased expression/transcripts of the cardiac sodium channels, SCN1b and SCN5a, altering the normal developmental trajectory of expression (Fahmi et al. 2004), suggesting potential consequences for cardiac function. Similarly, prenatal dexamethasone treatment in rats can cause lasting decreases in noradrenaline levels and turnover that persist into adulthood (Bian et al. 1993), suggesting that abnormal glucocorticoid exposure in early life could have a long lasting impact on cardiac sympathetic responses.

In late gestation, glucocorticoids accelerate the maturation of energy metabolism in the foetal heart. In rats, foetal dexamethasone exposure (at a time when endogenous corticosterone levels have peaked) increased ATP levels and delivery of ATP to myofibrils (Tsuzuki et al. 2009, Mizuno et al. 2010). It also increased levels of pyruvate and lactate in foetal heart and blood respectively (Jensen et al. 2002, Tsuzuki et al. 2009), suggesting increased glycolysis. Increased capacity to generate ATP in the late gestation foetal heart is likely to be critical to cope with the increased energy demand at birth. On the other hand, precocious maturation of oxidative energy production in a very immature foetal heart could be detrimental if energy substrates or oxygen levels subsequently become limiting and could increase reactive oxygen species.

\section{Long-term consequences of prematurity and/or antenatal glucocorticoid therapy: alterations in the normal trajectory of heart maturation?}

Animal studies have clearly shown that prenatal glucocorticoid administration increases blood pressure in adult offspring (reviewed Barker \& Fall (1993), Benediktsson et al. (1993) and Dodic et al. (2003)). However, these models usually involve early and/or extended intervention in otherwise healthy foetuses. In humans it is difficult to disentangle the effects of glucocorticoid insufficiency associated with immaturity from the effects of antenatal glucocorticoid therapy, as these situations normally go hand-in-hand. Moreover, glucocorticoid administration preceding premature delivery has only become routine in the last 30-40 years, so the longer term effects on cardiovascular outcomes may yet unfold. Nonetheless, most studies to date do not report any deleterious effects of antenatal glucocorticoid therapy on blood pressure, heart rate or overall cardiac performance (systolic or diastolic)

Published by Bioscientifica Ltd. 
in neonates, children, adolescents or in adults at 30 years of age (Dalziel et al. 2004, 2005, de Vries et al. 2008). A few follow-up studies report that children exposed to antenatal corticosteroids have moderately heightened systolic and diastolic blood pressures at the age of 7 (Wilson et al. 2006) and 14 (Doyle et al. 2000), although none were in the hypertensive range. However, prematurity and/or antenatal glucocorticoid therapy may alter the normal trajectory of postnatal heart development and function (Bensley et al. 2010). Interestingly, the hearts of young adults that were born premature have been reported to have a unique three-dimensional left ventricular shape with a displaced apex and shorter ventricular length and increased left ventricular mass (Lewandowski et al. 2013). This is associated with reduced systolic torsion/rotation of the ventricle. Whether this functional change is prenatally determined (including via antenatal glucocorticoid treatment) or due to a premature adaptation to postnatal life is currently unclear. Nevertheless, the lack of alignment of the outermost circumferential muscle fibres in $\mathrm{GR}^{-/-}$ foetuses (Rog-Zielinska et al. 2013) suggests that maturation of systolic twisting could be a glucocorticoidregulated process. These aspects of prematurity and/or glucocorticoid action will be important to further investigate in animal models. Whether these structural and functional changes result in abnormal responses to cardiac insults or haemodynamic load in later life is clearly of great interest and remains unproven at this stage. Other aspects of cardiac development, including the electrical conducting system of the heart, are known to be affected by prematurity. For example, adults born premature show a prolonged QT interval and increased QT dispersion, making them more vulnerable to ventricular arrhythmias (Bassareo et al. 2011), supporting the notion of increased cardiovascular risk.

A further difficulty encountered clinically is distinguishing the effects of small foetal size due to immaturity from other causes of intra-uterine growth restriction (IUGR). Haemodynamic adaptions to glucocorticoids may differ in IUGR foetuses (Hodges \& Wallace 2012) and indeed, foetal growth restriction can be associated with glucocorticoid excess, for example as a result of 11ß-HSD2 deficiency (Holmes et al. 2006, Seckl \& Holmes 2007). Because IUGR foetuses are at increased risk of premature birth, they are also likely to receive antenatal glucocorticoid therapy. The wisdom of this has recently been questioned (Hodges \& Wallace 2012). IUGR is associated with altered heart shape (more globular-shaped ventricles) and function (reduced stroke volume and subclinical systolic dysfunction) in children, the majority of which also receive antenatal glucocorticoid treatment (Crispi et al. 2010). Whilst there is no evidence that the risks of antenatal glucocorticoid therapy outweigh the benefits in this group, more follow-up studies focussed on the cardiac consequences are clearly warranted.

\section{Implications and concluding remarks}

Medical advances have led to more widespread use of antenatal glucocorticoid therapy, with intervention earlier in gestation, and greater use of repeat courses of glucocorticoids. Whilst it is clear that this therapy has reduced perinatal mortality and morbidity, clinicians have focused on early neonatal outcomes. Long-term effects of the high doses in routine use, particularly on the developing heart, remain unclear. Data from animal models, including non-human primates, suggest dosedependent programming effects of antenatal dexamethasone on cardiovascular risk factors (Bian et al. 1990, de Vries et al. 2007). The large-scale randomised clinical trials that first demonstrated the benefits of antenatal glucocorticoid therapy included few below 30 weeks gestation, yet the same therapy is now applied from 24 weeks, often with repeat doses.

Most clinical trials suggest that sustained exposure or repeated doses of corticosteroids are more effective in improving foetal outcomes (Abbasi et al. 2000, Crowther et al. 2006, Murphy et al. 2008, Asztalos et al. 2010). However, there is also a considerable body of evidence to suggest that multiple dosing does not carry any additional respiratory or cardiovascular benefits for the infant and is more detrimental for foetal growth and postnatal neurodevelopment, as well as adrenal function, compared with a single dose (Banks et al. 1999, Spinillo et al. 2004, Nair \& Omar 2009, Bontis et al. 2011, Murphy et al. 2012).

Clinically, betamethasone or dexamethasone is used, yet actions of the endogenous hormone, cortisol via MR, may be important for some of the normal maturational effects of endogenous glucocorticoids (such considerations do not apply to lung, where MR is co-expressed with 11ß-HSD2). Individual sensitivity to glucocorticoids may influence responses to therapy; the exon $9 \beta$ polymorphism in the NR3C1 gene encoding GR is associated with relative glucocorticoid resistance and also with higher blood pressure and left ventricular mass in children (Geelhoed et al. 2011). Thus, there is an important need to understand the normal actions of glucocorticoids on the foetal heart to address how timing and dose of glucocorticoid treatment might impact upon its developmental trajectory. Increasingly, therapy can be tailored to the

Published by Bioscientifica Ltd. 
individual and in future detailed foetal echocardiography should allow better diagnosis of possible cardiac dysfunction and distinction between the growth-restricted foetus and the immature foetus. This tailored therapy approach might ensure that the most appropriate steroid regime is used to minimise long-term adverse effects, particularly on the heart.

\section{Declaration of interest}

The authors declare that there is no conflict of interest that could be perceived as prejudicing the impartiality of the review reported.

\section{Funding}

E A R-Z is supported by the Transition Award from the British Heart Foundation Centre of Research Excellence and work in the authors laboratory has been supported by the British Heart Foundation and the Medical Research Council.

\section{Acknowledgements}

The authors are grateful to their colleagues, especially Gillian Gray, Megan Holmes and Chris Kenyon, for helpful discussions.

\section{References}

Abbasi S, Hirsch D, Davis J, Tolosa J, Stouffer N, Debbs R \& Gerdes JS 2000 Effect of single versus multiple courses of antenatal corticosteroids on maternal and neonatal outcome. American Journal of Obstetrics and Gynecology 182 1243-1249. (doi:10.1067/mob.2000.104789)

Asztalos EV, Murphy KE, Hannah ME, Willan AR, Matthews SG, Ohlsson A, Kelly EN, Saigal S, Ross S, Delisle MF et al. 2010 Multiple courses of antenatal corticosteroids for preterm birth study: 2-year outcomes. Pediatrics 126 e1045-e1055. (doi:10.1542/peds.2010-0857)

Ballard PL \& Ballard RA 1974 Cytoplasmic receptor for glucocorticoids in lung of the human fetus and neonate. Journal of Clinical Investigation $\mathbf{5 3}$ 477-486. (doi:10.1172/JCI107581)

Banks BA, Cnaan A, Morgan MA, Parer JT, Merrill JD, Ballard PL \& Ballard RA 1999 Multiple courses of antenatal corticosteroids and outcome of premature neonates. North American Thyrotropin-Releasing Hormone Study Group. American Journal of Obstetrics and Gynecology 181 709-717. (doi:10.1016/S0002-9378(99)70517-X)

Barker DJ \& Fall CH 1993 Fetal and infant origins of cardiovascular disease. Archives of Disease in Childhood 68 797-799. (doi:10.1136/adc.68.6.797)

Bartelds B, Knoester H, Smid GB, Takens J, Visser GH, Penninga L, van der Leij FR, Beaufort-Krol GC, Zijlstra WG, Heymans HS et al. 2000 Perinatal changes in myocardial metabolism in lambs. Circulation 102 926-931. (doi:10.1161/01.CIR.102.8.926)

Bassareo PP, Fanos V, Puddu M, Cadeddu C, Balzarini M \& Mercuro G 2011 Significant QT interval prolongation and long QT in young adult ex-preterm newborns with extremely low birth weight. Journal of Maternal-fetal \& Neonatal Medicine 24 1115-1118. (doi:10.3109/ 14767058.2010.543600)

Bayo P, Sanchis A, Bravo A, Cascallana JL, Buder K, Tuckermann J, Schütz G \& Pérez P 2008 Glucocorticoid receptor is required for skin barrier competence. Endocrinology 149 1377-1388. (doi:10.1210/ en.2007-0814)
Bellini C, Hennekam RC, Fulcheri E, Rutigliani M, Morcaldi G, Boccardo F \& Bonioli E 2009 Etiology of nonimmune hydrops fetalis: a systematic review. American Journal of Medical Genetics. Part A 149A 844-851. (doi:10.1002/ajmg.a.32655)

Benediktsson R, Lindsay R, Noble J, Seckl JR \& Edwards CR 1993 Glucocorticoid exposure in utero: a new model for adult hypertension. Lancet 341 339-341. (doi:10.1016/0140-6736(93)90138-7)

Bensley JG, Stacy VK, De Matteo R, Harding R \& Black MJ 2010 Cardiac remodelling as a result of pre-term birth: implications for future cardiovascular disease. European Heart Journal 31 2058-2066. (doi:10.1093/eurheartj/ehq104)

Berger SA, Cole TJ, Schmid W \& Schütz G 1996 Molecular genetic analysis of glucocorticoid and mineralocorticoid signaling in development and physiological processes. Steroids 61 236-239. (doi:10.1016/ 0039-128X(96)00029-3)

Bian XP, Seidler FJ, Bartolome J, Kavlock RJ, Bartolome M \& Slotkin TA 1990 Dose-dependent effect of prenatal dexamethasone treatment on $\beta$-adrenergic receptor coupling to ornithine decarboxylase and cyclic AMP. Journal of Developmental Physiology 14 125-130.

Bian X, Seidler FJ \& Slotkin TA 1993 Fetal dexamethasone exposure interferes with establishment of cardiac noradrenergic innervation and sympathetic activity. Teratology 47 109-117. (doi:10.1002/ tera.1420470203)

Bingham BC, Sheela Rani CS, Frazer A, Strong R \& Morilak DA 2013 Exogenous prenatal corticosterone exposure mimics the effects of prenatal stress on adult brain stress response systems and fear extinction behavior. Psychoneuroendocrinology 38 2746-2757. (doi:10.1016/j.psyneuen.2013.07.003)

Bleich M, Warth R, Schmidt-Hieber M, Schulz-Baldes A, Hasselblatt P, Fisch D, Berger S, Kunzelmann K, Kriz W, Schütz G et al. 1999 Rescue of the mineralocorticoid receptor knock-out mouse. Pflügers Archiv: European Journal of Physiology 438 245-254. (doi:10.1007/s004240050906)

Bontis N, Vavilis D, Tsolakidis D, Goulis DG, Tzevelekis P, Kellartzis D \& Tarlatzis BC 2011 Comparison of single versus multiple courses of antenatal betamethasone in patients with threatened preterm labor. Clinical and Experimental Obstetrics \& Gynecology 38 165-167.

Brown RW, Diaz R, Robson AC, Kotelevtsev YV, Mullins JJ, Kaufman MH \& Seckl JR 1996 The ontogeny of 11 $\beta$-hydroxysteroid dehydrogenase type 2 and mineralocorticoid receptor gene expression reveal intricate control of glucocorticoid action in development. Endocrinology 137 794-797. (doi:10.1210/en.137.2.794)

Brown RW, Diaz R, Robson AC, Kotelevtsev YV, Mullins JJ, Kaufman MH \& Seckl JR 2005 Glucocorticoid action in development. Current Opinion in Endocrinology and Diabetes 12 224-232. (doi:10.1097/01.med. 0000162081.03216.e0)

Buckingham JC 2006 Glucocorticoids: exemplars of multi-tasking. British Journal of Pharmacology 147 (Suppl 1) S258-S268. (doi:10.1038/ sj.bjp.0706456)

Burrell JH, Boyn AM, Kumarasamy V, Hsieh A, Head SI \& Lumbers ER 2003 Growth and maturation of cardiac myocytes in fetal sheep in the second half of gestation. Anatomical Record. Part A, Discoveries in Molecular, Cellular, and Evolutionary Biology 274 952-961. (doi:10.1002/ ar.a.10110)

Canale ED, Campbell GR, Smolich JJ \& Campbell JH 1986 In Handbook of Microscopic Anatomy. Cardiac Muscle. Heidelberg, Germany: Springer-Varlag.

Chapman KE, Holmes MC \& Seckl JR 2013 11ß-Hydroxysteroid dehydrogenases: intracellular gate-keepers of tissue glucocorticoid action. Physiological Reviews 93 1139-1206. (doi:10.1152/physrev.00020.2012)

Charmandari E, Kino T \& Chrousos GP 2004 Familial/sporadic glucocorticoid resistance: clinical phenotype and molecular mechanisms. Annals of the New York Academy of Sciences 1024 168-181. (doi:10.1196/ annals.1321.014)

Christoffels VM, Habets PE, Franco D, Campione M, de Jong F, Lamers WH, Bao ZZ, Palmer S, Biben C, Harvey RP et al. 2000 Chamber formation 
and morphogenesis in the developing mammalian heart. Developmental Biology 223 266-278. (doi:10.1006/dbio.2000.9753)

Ciccone MM, Scicchitano P, Zito A, Gesualdo M, Sassara M, Calderoni G, Di Mauro F, Ladisa G, Di Mauro A \& Laforgia N 2011 Different functional cardiac characteristics observed in term/preterm neonates by echocardiography and tissue Doppler imaging. Early Human Development 87 555-558. (doi:10.1016/j.earlhumdev.2011.04.012)

Clyman RI, Mauray F, Roman C, Heymann MA, Ballard PL, Rudolph AM \& Payne B 1981 Effects of antenatal glucocorticoid administration on ductus arteriosus of preterm lambs. American Journal of Physiology $241 \mathrm{H} 415-\mathrm{H} 420$.

Cole TJ, Blendy JA, Monaghan AP, Krieglstein K, Schmid W, Aguzzi A, Fantuzzi G, Hummler E, Unsicker K \& Schütz G 1995 Targeted disruption of the glucocorticoid receptor gene blocks adrenergic chromaffin cell development and severely retards lung maturation. Genes and Development 9 1608-1621. (doi:10.1101/gad.9.13.1608)

Corrigan N, Brazil DP \& McAuliffe FM 2010 High-frequency ultrasound assessment of the murine heart from embryo through to juvenile. Reproductive Sciences 17 147-157. (doi:10.1177/1933719109348923)

Cottrell EC \& Seckl JR 2009 Prenatal stress, glucocorticoids and the programming of adult disease. Frontiers in Behavioral Neuroscience 319. (doi:10.3389/neuro.08.019.2009)

Cottrell EC, Holmes MC, Livingstone DE, Kenyon CJ \& Seckl JR 2012 Reconciling the nutritional and glucocorticoid hypotheses of fetal programming. FASEB Journal 26 1866-1874. (doi:10.1096/ fj.12-203489)

Crispi F, Bijnens B, Figueras F, Bartrons J, Eixarch E, Le Noble F, Ahmed A \& Gratacós E 2010 Fetal growth restriction results in remodeled and less efficient hearts in children. Circulation 121 2427-2436. (doi:10.1161/ CIRCULATIONAHA.110.937995)

Crowther CA, Haslam RR, Hiller JE, Doyle LW, Robinson JS \& Group ACToRDoSAS 2006 Neonatal respiratory distress syndrome after repeat exposure to antenatal corticosteroids: a randomised controlled trial. Lancet 367 1913-1919. (doi:10.1016/S0140-6736(06)68846-6)

Crump C, Sundquist K, Sundquist J \& Winkleby MA 2011 Gestational age at birth and mortality in young adulthood. Journal of the American Medical Association 306 1233-1240. (doi:10.1001/jama.2011.1331)

Curran PF, Jelin EB, Rand L, Hirose S, Feldstein VA, Goldstein RB \& Lee H 2010 Prenatal steroids for microcystic congenital cystic adenomatoid malformations. Journal of Pediatric Surgery 45 145-150. (doi:10.1016/ j.jpedsurg.2009.10.025)

Dalziel SR, Liang A, Parag V, Rodgers A \& Harding JE 2004 Blood pressure at 6 years of age after prenatal exposure to betamethasone: follow-up results of a randomized, controlled trial. Pediatrics 114 e373-e377. (doi:10.1542/peds.2004-0196)

Dalziel SR, Walker NK, Parag V, Mantell C, Rea HH, Rodgers A \& Harding JE 2005 Cardiovascular risk factors after antenatal exposure to betamethasone: 30-year follow-up of a randomised controlled trial. Lancet 365 1856-1862. (doi:10.1016/S0140-6736(05)66617-2)

Davies MP, An RH, Doevendans P, Kubalak S, Chien KR \& Kass RS 1996 Developmental changes in ionic channel activity in the embryonic murine heart. Circulation Research 78 15-25. (doi:10.1161/ 01.RES.78.1.15)

Dodic M, Moritz K \& Wintour EM 2003 Prenatal exposure to glucocorticoids and adult disease. Archives of Physiology and Biochemistry 111 61-69. (doi:10.1076/apab.111.1.61.15144)

Donaldson A, Nicolini U, Symes EK, Rodeck CH \& Tannirandorn Y 1991 Changes in concentrations of cortisol, dehydroepiandrosterone sulphate and progesterone in fetal and maternal serum during pregnancy. Clinical Endocrinology 35 447-451. (doi:10.1111/ j.1365-2265.1991.tb03564.x)

Dooley R, Harvey BJ \& Thomas W 2012 Non-genomic actions of aldosterone: from receptors and signals to membrane targets. Molecular and Cellular Endocrinology 350 223-234. (doi:10.1016/j.mce. 2011.07.019)
Doyle LW, Ford GW, Davis NM \& Callanan C 2000 Antenatal corticosteroid therapy and blood pressure at 14 years of age in preterm children. Clinical Science 98 137-142. (doi:10.1042/CS19990211)

Ehler E, Rothen BM, Hämmerle SP, Komiyama M \& Perriard JC 1999 Myofibrillogenesis in the developing chicken heart: assembly of Z-disk, M-line and the thick filaments. Journal of Cell Science 112 1529-1539.

Eronen M, Kari A, Pesonen E \& Hallman M 1993 The effect of antenatal dexamethasone administration on the fetal and neonatal ductus arteriosus. A randomized double-blind study. American Journal of Diseases of Children 147 187-192. (doi:10.1001/archpedi.1993. 02160260077026)

Fahmi AI, Forhead AJ, Fowden AL \& Vandenberg JI 2004 Cortisol influences the ontogeny of both $\alpha$ - and $\beta$-subunits of the cardiac sodium channel in fetal sheep. Journal of Endocrinology 180 449-455. (doi:10.1677/joe.0. 1800449)

Feng X, Reini S, Richards E, Wood CE \& Keller-Wood M 2013 Cortisol stimulates proliferation and apoptosis in the late gestation fetal heart: differential effects of mineralocorticoid and glucocorticoid receptors. American Journal of Physiology. Regulatory, Integrative and Comparative Physiology 305 343-350. (doi:10.1152/ajpregu.00112.2013)

Fernandez EF \& Watterberg KL 2009 Relative adrenal insufficiency in the preterm and term infant. Journal of Perinatology 29 (Suppl 2) S44-S49. (doi:10.1038/ip.2009.24)

Fowden AL, Li J \& Forhead AJ 1998 Glucocorticoids and the preparation for life after birth: are there long-term consequences of the life insurance? Proceedings of the Nutrition Society 57 113-122. (doi:10.1079/ PNS19980017)

Fraccarollo D, Berger S, Galuppo P, Kneitz S, Hein L, Schütz G, Frantz S, Ertl G \& Bauersachs J 2011 Deletion of cardiomyocyte mineralocorticoid receptor ameliorates adverse remodeling after myocardial infarction. Circulation 123 400-408. (doi:10.1161/CIRCULATIONAHA. 110.983023)

Fritsch A, Müller AL, Sanseverino MT, Kessler RG, Barrios PM, Patusco LM \& Magalhães JA 2012 Nonimmune hydrops fetalis: two decades of experience in a university hospital. Revista Brasileira de Ginecologia e Obstetrícia 34 310-315. (doi:10.1590/S0100-72032012000700004)

Funder JW 1997 Glucocorticoid and mineralocorticoid receptors: biology and clinical relevance. Annual Review of Medicine 48 231-240. (doi:10.1146/annurev.med.48.1.231)

Funder JW 2005 Mineralocorticoid receptors: distribution and activation. Heart Failure Reviews 10 15-22. (doi:10.1007/s10741-005-2344-2)

Geelhoed JJ, van Duijn C, van Osch-Gevers L, Steegers EA, Hofman A, Helbing WA \& Jaddoe VW 2011 Glucocorticoid receptor-9 $\beta$ polymorphism is associated with systolic blood pressure and heart growth during early childhood. The Generation R Study. Early Human Development 87 97-102. (doi:10.1016/j.earlhumdev.2010.11.006)

Giraud GD, Louey S, Jonker S, Schultz J \& Thornburg KL 2006 Cortisol stimulates cell cycle activity in the cardiomyocyte of the sheep fetus. Endocrinology 147 3643-3649. (doi:10.1210/en.2006-0061)

Harada K, Rice MJ, Shiota T, Ishii M, McDonald RW, Reller MD \& Sahn DJ 1997 Gestational age- and growth-related alterations in fetal right and left ventricular diastolic filling patterns. American Journal of Cardiology 79 173-177. (doi:10.1016/S0002-9149(96)00706-0)

Harada K, Takahashi Y, Tamura M, Orino T \& Takada G 1999 Serial echocardiographic and Doppler evaluation of left ventricular systolic performance and diastolic filling in premature infants. Early Human Development 54 169-180. (doi:10.1016/S0378-3782(98)00093-0)

Henderson DJ \& Anderson RH 2009 The development and structure of the ventricles in the human heart. Pediatric Cardiology 30 588-596. (doi:10.1007/s00246-009-9390-9)

Hirschy A, Schatzmann F, Ehler E \& Perriard JC 2006 Establishment of cardiac cytoarchitecture in the developing mouse heart. Developmental Biology 289 430-441. (doi:10.1016/j.ydbio.2005.10.046)

Hodges RJ \& Wallace EM 2012 Mending a growth-restricted fetal heart: should we use glucocorticoids? Journal of Maternal-fetal \& Neonatal Medicine 25 2149-2153. (doi:10.3109/14767058.2012.697940) 
Holmes MC, Abrahamsen CT, French KL, Paterson JM, Mullins JJ \& Seckl JR 2006 The mother or the fetus? 11ß-Hydroxysteroid dehydrogenase type 2 null mice provide evidence for direct fetal programming of behavior by endogenous glucocorticoids Journal of Neuroscience $\mathbf{2 6}$ 3840-3844. (doi:10.1523/JNEUROSCI.4464-05.2006)

Huhta JC 2005 Fetal congestive heart failure. Seminars in Fetal \& Neonatal Medicine 10 542-552. (doi:10.1016/j.siny.2005.08.005)

Ibrahim H, Sinha IP \& Subhedar NV 2011 Corticosteroids for treating hypotension in preterm infants. Cochrane Database of Systematic Reviews CD003662. (doi:10.1002/14651858.CD003662.pub4)

Jensen EC, Gallaher BW, Breier BH \& Harding JE 2002 The effect of a chronic maternal cortisol infusion on the late-gestation fetal sheep. Journal of Endocrinology 174 27-36. (doi:10.1677/joe.0.1740027)

Kluckow M 2005 Low systemic blood flow and pathophysiology of the preterm transitional circulation. Early Human Development 81 429-437. (doi:10.1016/j.earlhumdev.2005.03.006)

Knox EM, Kilby MD, Martin WL \& Khan KS 2006 In-utero pulmonary drainage in the management of primary hydrothorax and congenital cystic lung lesion: a systematic review. Ultrasound in Obstetrics \& Gynecology 28 726-734. (doi:10.1002/uog.3812)

Kozák-Bárány A, Jokinen E, Saraste M, Tuominen J \& Välimäki I 2001 Development of left ventricular systolic and diastolic function in preterm infants during the first month of life: a prospective follow-up study. Journal of Pediatrics 139 539-545. (doi:10.1067/mpd.2001. 118199)

Langley-Evans SC 2013 Fetal programming of CVD and renal disease: animal models and mechanistic considerations. Proceedings of the Nutrition Society 72 317-325. (doi:10.1017/S0029665112003035)

Langley-Evans SC, Gardner DS \& Welham SJ 1998 Intrauterine programming of cardiovascular disease by maternal nutritional status. Nutrition 14 39-47. (doi:10.1016/S0899-9007(97)00391-2)

Leung WC, Ngai C, Lam TP, Chan KL, Lao TT \& Tang MH 2005 Unexpected intrauterine death following resolution of hydrops fetalis after betamethasone treatment in a fetus with a large cystic adenomatoid malformation of the lung. Ultrasound in Obstetrics \& Gynecology 25 610-612. (doi:10.1002/uog.1912)

Lewandowski AJ, Augustine D, Lamata P, Davis EF, Lazdam M, Francis J, McCormick K, Wilkinson AR, Singhal A, Lucas A et al. 2013 Preterm heart in adult life: cardiovascular magnetic resonance reveals distinct differences in left ventricular mass, geometry, and function. Circulation 127 197-206. (doi:10.1161/CIRCULATIONAHA.112.126920)

Louey S \& Thornburg KL 2005 The prenatal environment and later cardiovascular disease. Early Human Development 81 745-751. (doi:10.1016/j.earlhumdev.2005.07.001)

Mastorakos G \& Ilias I 2003 Maternal and fetal hypothalamic-pituitaryadrenal axes during pregnancy and postpartum. Annals of the New York Academy of Sciences 997 136-149. (doi:10.1196/annals.1290.016)

McEwen BS 1997 The brain is an important target of adrenal steroid actions. A comparison of synthetic and natural steroids. Annals of the New York Academy of Sciences 823 201-213. (doi:10.1111/j.1749-6632. 1997.tb48392.x)

Messaoudi S, Azibani F, Delcayre C \& Jaisser F 2012 Aldosterone, mineralocorticoid receptor, and heart failure. Molecular and Cellular Endocrinology 350 266-272. (doi:10.1016/j.mce.2011.06.038)

Michelsohn AM \& Anderson DJ 1992 Changes in competence determine the timing of 2 sequential glucocorticoid effects on sympathoadrenal progenitors. Neuron 8 589-604. (doi:10.1016/0896-6273(92)90285-L)

Mizuno M, Takeba Y, Matsumoto N, Tsuzuki Y, Asoh K, Takagi M, Kobayashi S \& Yamamoto H 2010 Antenatal glucocorticoid therapy accelerates ATP production with creatine kinase increase in the growthenhanced fetal rat heart. Circulation Journal 74 171-180. (doi:10.1253/ circj.CJ-09-0311)

Montano MM, Wang MH \& vom Saal FS 1993 Sex differences in plasma corticosterone in mouse fetuses are mediated by differential placental transport from the mother and eliminated by maternal adrenalectomy or stress. Journal of Reproduction and Fertility 99 283-290. (doi:10.1530/ jrf.0.0990283)

Mulder EJ, de Heus R \& Visser GH 2009 Antenatal corticosteroid therapy: short-term effects on fetal behaviour and haemodynamics. Seminars in Fetal \& Neonatal Medicine 14 151-156. (doi:10.1016/j.siny.2008.10.003)

Munck A, Guyre PM \& Holbrook NJ 1984 Physiological functions of glucocorticoids in stress and their relationship to pharmacological actions. Endocrinology Reviews 5 25-44. (doi:10.1210/edrv-5-1-25)

Murphy VE \& Clifton VL 2003 Alterations in human placental 11ßhydroxysteroid dehydrogenase type 1 and 2 with gestational age and labour. Placenta 24 739-744. (doi:10.1016/S0143-4004(03)00103-6)

Murphy KE, Hannah ME, Willan AR, Hewson SA, Ohlsson A, Kelly EN, Matthews SG, Saigal S, Asztalos E, Ross S et al. 2008 Multiple courses of antenatal corticosteroids for preterm birth (MACS): a randomised controlled trial. Lancet 372 2143-2151. (doi:10.1016/S01406736(08)61929-7)

Murphy KE, Willan AR, Hannah ME, Ohlsson A, Kelly EN, Matthews SG, Saigal S, Asztalos E, Ross S, Delisle MF et al. 2012 Effect of antenatal corticosteroids on fetal growth and gestational age at birth. Obstetrics and Gynecology 119 917-923. (doi:10.1097/AOG.0b013e31825189dc)

Nair GV \& Omar SA 2009 Blood pressure support in extremely premature infants is affected by different courses of antenatal steroids. Acta Paediatrica 98 1437-1443. (doi:10.1111/j.1651-2227.2009.01367.x)

Nemati B, Atmodjo W, Gagnon S, Humes D, McKerlie C, Kaplan F \& Sweezey NB 2008 Glucocorticoid receptor disruption delays structural maturation in the lungs of newborn mice. Pediatric Pulmonology $\mathbf{4 3}$ 125-133. (doi:10.1002/ppul.20746)

Ng PC, Lee CH, Lam CW, Ma KC, Fok TF, Chan IH \& Wong E 2004 Transient adrenocortical insufficiency of prematurity and systemic hypotension in very low birthweight infants. Archives of Disease in Childhood. Fetal and Neonatal Edition 89 F119-F126. (doi:10.1136/ adc.2002.021972)

Noori S, Siassi B, Durand M, Acherman R, Sardesai S \& Ramanathan R 2006 Cardiovascular effects of low-dose dexamethasone in very low birth weight neonates with refractory hypotension. Biology of the Neonate 89 82-87. (doi:10.1159/000088289)

Nyirenda MJ, Lindsay RS, Kenyon CJ, Burchell A \& Seckl JR 1998 Glucocorticoid exposure in late gestation permanently programs rat hepatic phosphoenolpyruvate carboxykinase and glucocorticoid receptor expression and causes glucose intolerance in adult offspring. Journal of Clinical Investigation 101 2174-2181. (doi:10.1172/JCI1567)

Nykänen P, Anttila E, Heinonen K, Hallman M \& Voutilainen R 2007 Early hypoadrenalism in premature infants at risk for bronchopulmonary dysplasia or death. Acta Paediatrica 96 1600-1605. (doi:10.1111/ j.1651-2227.2007.00500.x)

Oparil S, Bishop SP \& Clubb FJ 1984 Myocardial cell hypertrophy or hyperplasia. Hypertension 6 III38-III43. (doi:10.1161/01.HYP. 6.6_Pt_2.III38)

Opherk C, Tronche F, Kellendonk C, Kohlmüller D, Schulze A, Schmid W \& Schütz G 2004 Inactivation of the glucocorticoid receptor in hepatocytes leads to fasting hypoglycemia and ameliorates hyperglycemia in streptozotocin-induced diabetes mellitus. Molecular Endocrinology 18 1346-1353. (doi:10.1210/me.2003-0283)

O'Sullivan L, Cuffe JS, Paravicini TM, Campbell S, Dickinson H, Singh RR, Gezmish O, Black MJ \& Moritz KM 2013 Prenatal exposure to dexamethasone in the mouse alters cardiac growth patterns and increases pulse pressure in aged male offspring. PLoS ONE 8 e69149. (doi:10.1371/journal.pone.0069149)

Rapila R, Korhonen T \& Tavi P 2008 Excitation-contraction coupling of the mouse embryonic cardiomyocyte. Journal of General Physiology 132 397-405. (doi:10.1085/jgp.200809960)

Reynolds RM 2013 Programming effects of glucocorticoids. Clinical Obstetrics and Gynecology 56 602-609. (doi:10.1097/GRF. Ob013e31829939f7)

Rog-Zielinska EA, Thomson A, Kenyon CJ, Brownstein DG, Moran CM, Szumska D, Michailidou Z, Richardson J, Owen E, Watt A et al. 2013 
Glucocorticoid receptor is required for foetal heart maturation. Human Molecular Genetics 22 3269-3282. (doi:10.1093/hmg/ddt182)

Roseboom TJ, van der Meulen JH, Ravelli AC, Osmond C, Barker DJ \& Bleker OP 2001 Effects of prenatal exposure to the Dutch famine on adult disease in later life: an overview. Molecular and Cellular Endocrinology 185 93-98. (doi:10.1016/S0303-7207(01)00721-3)

Rudolph AM, Roman C \& Gournay V 1999 Perinatal myocardial DNA and protein changes in the lamb: effect of cortisol in the fetus. Pediatric Research 46 141-146. (doi:10.1203/00006450-199908000-00002)

Samarasinghe RA, Witchell SF \& DeFranco DB 2012 Cooperativity and complementarity: synergies in non-classical and classical glucocorticoid signaling. Cell Cycle 11 2819-2827. (doi:10.4161/cc.21018)

Schmitz L, Xanthopoulos A, Koch H \& Lange PE 2004 Doppler flow parameters of left ventricular filling in infants: how long does it take for the maturation of the diastolic function in a normal left ventricle to occur? Pediatric Cardiology 25 482-491. (doi:10.1007/s00246-0030605-1)

Seckl JR \& Holmes MC 2007 Mechanisms of disease: glucocorticoids, their placental metabolism and fetal 'programming' of adult pathophysiology. Nature Clinical Practice. Endocrinology \& Metabolism 3 479-488. (doi:10.1038/ncpendmet0515)

Sehgal A 2011 Haemodynamically unstable preterm infant: an unresolved management conundrum. European Journal of Pediatrics $\mathbf{1 7 0}$ 1237-1245. (doi:10.1007/s00431-011-1435-4)

Siedner S, Krüger M, Schroeter M, Metzler D, Roell W, Fleischmann BK, Hescheler J, Pfitzer G \& Stehle R 2003 Developmental changes in contractility and sarcomeric proteins from the early embryonic to the adult stage in the mouse heart. Journal of Physiology 548 493-505. (doi:10.1113/jphysiol.2002.036509)

Slotkin TA, Seidler FJ, Kavlock RJ \& Bartolome JV 1991 Fetal dexamethasone exposure impairs cellular development in neonatal rat heart and kidney: effects on DNA and protein in whole tissues. Teratology $\mathbf{4 3}$ 301-306. (doi:10.1002/tera.1420430404)

Spinillo A, Viazzo F, Colleoni R, Chiara A, Maria Cerbo R \& Fazzi E 2004 Two-year infant neurodevelopmental outcome after single or multiple antenatal courses of corticosteroids to prevent complications of prematurity. American Journal of Obstetrics and Gynecology 191 217-224. (doi:10.1016/j.ajog.2003.12.023)

Tegethoff M, Pryce C \& Meinlschmidt G 2009 Effects of intrauterine exposure to synthetic glucocorticoids on fetal, newborn, and infant hypothalamic-pituitary-adrenal axis function in humans: a systematic review. Endocrine Reviews 30 753-789. (doi:10.1210/er.2008-0014)

Thompson A, Han VK \& Yang K 2002 Spatial and temporal patterns of expression of 11 $\beta$-hydroxysteroid dehydrogenase types 1 and 2 messenger RNA and glucocorticoid receptor protein in the murine placenta and uterus during late pregnancy. Biology of Reproduction $\mathbf{6 7}$ 1708-1718. (doi:10.1095/biolreprod.102.005488)

Torres A, Belser WW III, Umeda PK \& Tucker D 1997 Indicators of delayed maturation of rat heart treated prenatally with dexamethasone.
Pediatric Research 42 139-144. (doi:10.1203/00006450-19970800000001)

Tronche F, Kellendonk C, Reichardt HM \& Schütz G 1998 Genetic dissection of glucocorticoid receptor function in mice. Current Opinion in Genetics \& Development 8 532-538. (doi:10.1016/S0959-437X(98) 80007-5)

Tsao K, Hawgood S, Vu L, Hirose S, Sydorak R, Albanese CT, Farmer DL, Harrison MR \& Lee H 2003 Resolution of hydrops fetalis in congenital cystic adenomatoid malformation after prenatal steroid therapy. Journal of Pediatric Surgery 38 508-510. (doi:10.1053/jpsu.2003.50089)

Tsuzuki Y, Takeba Y, Kumai T, Matsumoto N, Mizuno M, Murano K, Asoh K, Takagi M, Yamamoto H \& Kobayashi S 2009 Antenatal glucocorticoid therapy increase cardiac $\alpha$-enolase levels in fetus and neonate rats. Life Sciences 85 609-616. (doi:10.1016/j.lfs.2009.06.017)

Unno N, Wong CH, Jenkins SL, Wentworth RA, Ding XY, Li C, Robertson SS, Smotherman WP \& Nathanielsz PW 1999 Blood pressure and heart rate in the ovine fetus: ontogenic changes and effects of fetal adrenalectomy. American Journal of Physiology 276 H248-H256.

de Vries A, Holmes MC, Heijnis A, Seier JV, Heerden J, Louw J, Wolfe-Coote S, Meaney MJ, Levitt NS \& Seckl JR 2007 Prenatal dexamethasone exposure induces changes in nonhuman primate offspring cardiometabolic and hypothalamic-pituitary-adrenal axis function. Journal of Clinical Investigation 117 1058-1067. (doi:10.1172/JCI30982)

de Vries WB, Karemaker R, Mooy NF, Strengers JL, Kemperman H, Baerts W, Veen S, Visser GH, Heijnen CJ \& van Bel F 2008 Cardiovascular followup at school age after perinatal glucocorticoid exposure in prematurely born children: perinatal glucocorticoid therapy and cardiovascular follow-up. Archives of Pediatrics \& Adolescent Medicine 162 738-744. (doi:10.1001/archpedi.162.8.738)

Walker CD, Scribner KA, Cascio CS \& Dallman MF 1991 The pituitaryadrenocortical system of neonatal rats is responsive to stress throughout development in a time-dependent and stressor-specific fashion. Endocrinology 128 1385-1395. (doi:10.1210/endo-128-3-1385)

Webb S, Brown NA \& Anderson RH 1996 The structure of the mouse heart in late fetal stages. Anatomy and Embryology 194 37-47. (doi:10.1007/ BF00196313)

Wilson TT, Waters L, Patterson CC, McCusker CG, Rooney NM, Marlow N \& Halliday HL 2006 Neurodevelopmental and respiratory follow-up results at 7 years for children from the United Kingdom and Ireland enrolled in a randomized trial of early and late postnatal corticosteroid treatment, systemic and inhaled (the Open Study of Early Corticosteroid Treatment). Pediatrics 117 2196-2205. (doi:10.1542/peds.2005-2194)

Yates AR, Welty SE, Gest AL \& Cua CL 2008 Myocardial tissue Doppler changes in patients with bronchopulmonary dysplasia. Journal of Pediatrics 152 766-770 (770.e1). (doi:10.1016/j.jpeds.2007.11.039)

Yoder B, Martin H, McCurnin DC \& Coalson JJ 2002 Impaired urinary cortisol excretion and early cardiopulmonary dysfunction in immature baboons. Pediatric Research 51 426-432. (doi:10.1203/00006450200204000-00006)

Received in final form 26 November 2013

Accepted 2 December 2013

Accepted Preprint published online 3 December 2013 http://jme.endocrinology-journals.org DOI: 10.1530/JME-13-0204
() 2014 Society for Endocrinology Printed in Great Britain
Published by Bioscientifica Ltd. 